\title{
The biological evaluation of urea, casein and gluten in the diets of sheep
}

\author{
By H. I. DEIF, K. EL-SHAZLY AND A. R. ABOU AKKADA \\ Department of Animal Production, Faculty of Agriculture, \\ University of Alexandria, Egypt, UAR
}

(Received 9 October 1967-Accepted 12 January 1968)

\begin{abstract}
I. Two adult Barki rams weighing $43 \mathrm{~kg}$ were each put on a practically nitrogen-free diet until they became clearly hypoproteinic. They were then given gluten, casein and urea as sources of $N$ at levels of $1 \cdot 33,3 \cdot 33,5 \cdot 33,7 \cdot 33,1 \times \cdot 33$ and $14.33 \mathrm{~g} N /$ day, and $N$ balance trials were carried out at each level.

2. Absorbed $\mathrm{N}$ (g/day) was plotted against $\mathrm{N}$ retention (g/day), and a straight-line relationship within certain limits was established. The slope $K$ (the $\mathbf{N}$ balance index of absorbed $N$ ) was found to be $0.65,1.05$, and 0.82 for casein, gluten and urea respectively.

3. Urea $N$ was utilized best at a level of $5.33 \mathrm{~g} \mathrm{~N} /$ day, and casein at levels of $11 \cdot 33$ and $14.33 \mathrm{~g} \mathrm{~N} /$ day. Gluten showed almost identical 'biological values' at all the levels tested.

4. It was possible to prove that urinary $\mathrm{N}(U)$ excreted when the rams were in $N$ equilibrium and were consuming rice gluten was equivalent to the endogenous urinary $N\left(U_{0}\right)$, thus verifying the equation of Allison (1949), $U=(\mathrm{I}-K) A+U_{0}$, where $A$ is the absorbed $\mathrm{N}$.
\end{abstract}

Mitchell (I943) and Allison (I949) recommended the use of 'biological value' as a useful assessment of the quality of different nitrogenous sources used in the nutrition of monogastric animals. On the other hand, Chalmers \& Synge (1954) suggested that nitrogen retention should be used as a measure of protein utilization. They concluded that the estimation of metabolic faecal $\mathrm{N}$ and endogenous urinary $\mathrm{N}$ was not practicable since the animals would have to exist on a $\mathrm{N}$-free diet for long periods and this would render their condition non-physiological. Allison (1949) criticized biological value measurements in monogastric animals on the same basis, i.e. that the determination of endogenous urinary $\mathrm{N}$ was unphysiological, and he described a method whereby a protein, that has a ' $K$ ' value equivalent to unity ( $K$ being the $\mathrm{N}$ balance index for absorbed $N$ ), is fed to animals in sufficient amounts just to bring them into $\mathrm{N}$ equilibrium. In these circumstances the urinary $\mathrm{N}$ excreted $(U)$ will be equivalent to the endogenous urinary $N\left(U_{0}\right)$. The protein found to have this value for dogs was lactalbumin.

An advantage of comparing the biological value of proteins on the basis of $K$ is that $K$ has been shown to be constant regardless of the degree of nitrogen reserves in the body. Also biological value is superior to $\mathrm{N}$ balance for assessing the nutritive value of a protein, because it is a measure of the extent to which the absorbed $\mathrm{N}$ is utilized by the animal.

The object of the present investigation was to study the possibility of using Allison's (1949) technique to determine the biological value of casein, urea and gluten in sheep. 


\section{MATERIALS AND METHODS}

Animals. Two Barki rams (nos. 655 and 749), each weighing $43 \mathrm{~kg}$ and aged about 2 years, were used throughout this work. At $09.00 \mathrm{~h}$ daily, each animal was given a basal ration consisting of wheat straw $500 \mathrm{~g}$, starch $300 \mathrm{~g}$ and mineral mixture (Ahmed \& el-Shazly, 1960) ${ }^{\circ} 5 \mathrm{~g}$. Every I 5 days each ram was given 50000 i.u. vitamin A and 5000 i.u. vitamin D.

$N$ balance experiments. The basal ration supplied practically no digestible $\mathrm{N}$. The animals were kept on this basal ration for 27 days (until urinary $\mathrm{N}$ excretion was almost constant for 4 days). The basal ration was then supplemented with casein $(13.81 \% \mathrm{~N})$ at levels which supplied the rams with $1 \cdot 33,3 \cdot 33,5 \cdot 33,7 \cdot 33$, I I.33 and I $4 \cdot 33 \mathrm{~g} \mathrm{~N} /$ day. After the last level of casein, the animals were put back on the $\mathrm{N}$-free basal ration until urinary $\mathrm{N}$ was again constant for 4 successive days ( 23 days). The basal ration was then supplemented with urea $(46.0 \%)$ at the same levels of $N$ used with casein. This was followed by a third period on the $\mathrm{N}$-free basal ration until urinary $\mathrm{N}$ was again constant for 4 successive days ( 8 days). Gluten $(5.35 \% \mathrm{~N})$ was added to the basal ration at the same $\mathrm{N}$ levels used for the other two sources. Rice gluten $(3 \circ 07 \% \mathrm{~N})$ was obtained from the Egyptian Starch Products and Yeast Company, Alexandria. It was washed with water to remove soluble nitrogenous substances and starch and was then dried. The true and non-protein nitrogen (NPN) were determined and found to be 5.27 and $0.08 \%$ respectively. A nitrogen balance experiment was carried out for each $\mathrm{N}$ level with each of the three sources of $\mathrm{N}$. A collection period of 5 days followed by 2 days of rest on the next level was undertaken. Urine and faeces were collected separately. Faeces were collected in plastic bags enclosed in cloth bags fitted on the animals with harnesses. The rams were put in metabolic cages and urine was collected in glass jars containing a few $\mathrm{ml}$ of conc. $\mathrm{H}_{2} \mathrm{SO}_{4}$. Both faeces and urine were analysed daily for $\mathrm{N}$ and dry matter.

With daily intakes of I $133 \mathrm{~g} \mathrm{~N}$, rumen samples were collected from each ram before it was fed (08.45 h) and at $\mathrm{I}, 2,3,5,7$ and $20 \mathrm{~h}$ after feeding.

At each level of gluten and casein supplementation an equivalent amount of starch was removed from the basal ration to keep the rations approximately isocaloric.

Measurement of urinary $N$ in sheep given cottonseed meal, gluten and a $N$-free diet. An experiment was done to show the changes that occurred in urinary $\mathrm{N}$ when the rams were given straw $(500 \mathrm{~g})$ supplemented with $300 \mathrm{~g}$ starch and $\mathrm{I} 60 \mathrm{~g}$ decorticated cottonseed meal to give an intake of $10 \mathrm{~g} \mathrm{~N} /$ day. The animals were then given gluten

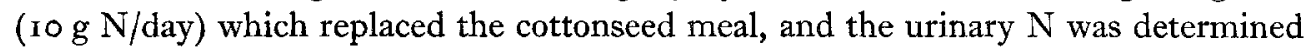
until it was constant for a period of 4 successive days. In the following period the animals were given straw and starch but no protein supplement and the urinary $\mathrm{N}$ was again determined for 5 successive days.

Analytical methods. Analyses of feedingstuffs and faeces were carried out according to the official methods of the Association of Official Agricultural Chemists (1955).

Total $\mathrm{N}$ in urine was estimated by the micro-Kjeldahl method (Chibnall, Rees \& Williams, I943) using the Markham micro-distillation apparatus (Markham, 1942). True protein in the feedstuffs was precipitated by Stutzer solution (Association of 
Official Agricultural Chemists, 1955) and then determined by the Kjeldahl method. NPN was determined by difference. Ammonia $\mathrm{N}$ was estimated in the rumen liquor by the method of Van Slyke (Hawk, Oser \& Summerson, 1952).

\section{RESULTS}

Relationship between $N$ intake and faecal $N$. Fig. I illustrates the relationship between $\mathrm{N}$ intake and faecal $\mathrm{N}$ when the two rams were given the control diet and the diets containing the six levels of casein, gluten or urea. It was noted that the metabolic faecal N was 2.48 and $3.24 \mathrm{~g} /$ day for the casein diet, 2.03 and $2.37 \mathrm{~g} /$ day for the urea

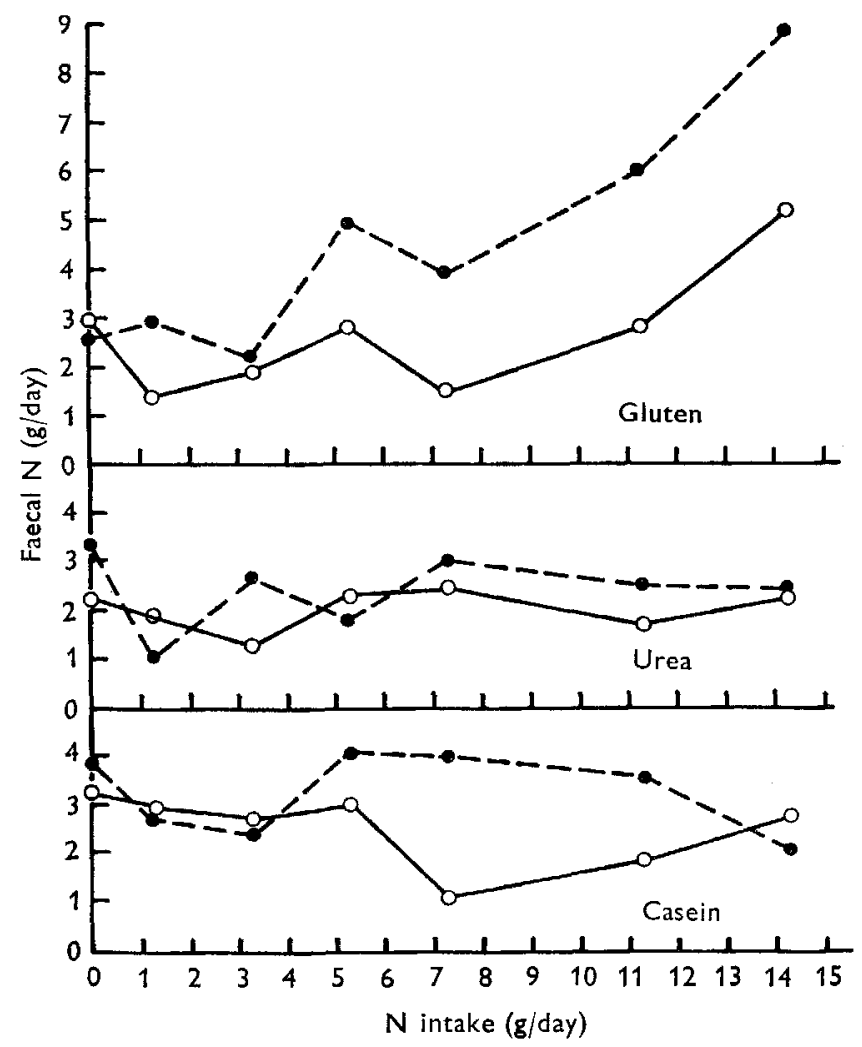

Fig. I. Relationship between nitrogen intake and faecal $\mathrm{N}$ in rams nos. $655,0-\mathrm{O}$, and 749 , - receiving diets containing casein, urea or gluten.

diet and $2 \cdot 1 \mathrm{I}$ and $3.28 \mathrm{~g} /$ day for the gluten diet for animals nos. 655 and 749 respectively, when each of them consumed $735 \mathrm{~g}$ dry matter/day. These figures are average values of faecal $\mathrm{N}$ at all levels of $\mathrm{N}$ intake in the case of urea and casein but only the average of the first four levels of $\mathrm{N}$ intake in the case of gluten.

The $\mathrm{N}$ excreted in the faeces was lowest when the animals were given urea or casein, whereas it was highest when they were given gluten at levels of $1 \mathrm{I} \cdot 33$ and $14.33 \mathrm{~g}$ $\mathrm{N} /$ day. An increase in $\mathrm{N}$ intake was followed by an increase in faecal $\mathrm{N}$ when gluten was offered to the animals, but this trend was not observed with casein and urea. 
Variation in production of ruminal ammonia with time when casein, gluten and urea were given. The concentrations of ammonia determined in the rumen liquor just before feeding and at six different intervals after feeding are shown in Fig. 2. The levels of ruminal ammonia when the animals were given casein were higher than when they were given gluten. When the animals received urea, the concentrations of ammonia were intermediate between those observed for the casein and gluten diets. The curve of ammonia production for all three sources of $\mathrm{N}$ started at a very low level just before feeding and then rose until it reached a maximum $2 \mathrm{~h}$ after feeding. There was very little individual variation in the ammonia contents of the rumen liquor with any of the diets.

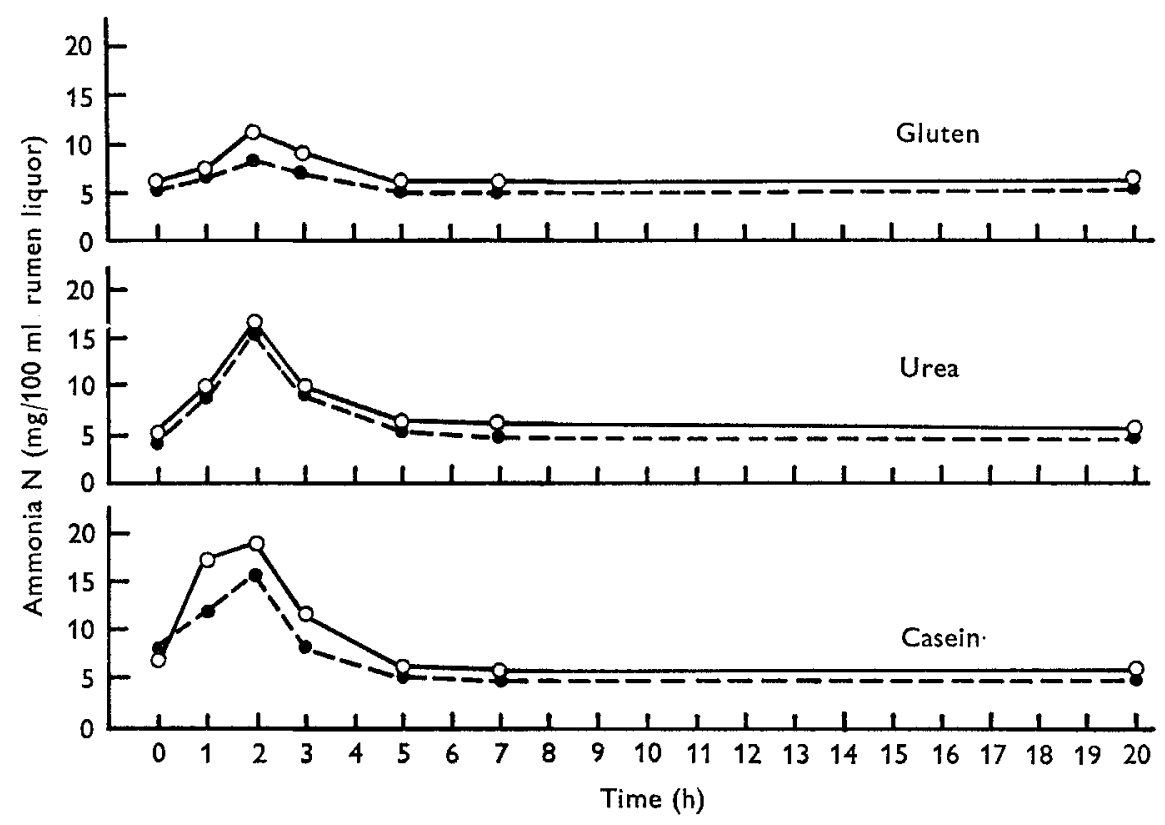

Fig. 2. Variation in the concentration of ammonia in the rumen of rams nos. $655,0-0$, and 749 , - - receiving $11.33 \mathrm{~g}$ nitrogen/day in the form of casein, urea or gluten.

Relationship between $N$ intake and urinary $N$. The relationship between $\mathrm{N}$ intake and urinary $\mathrm{N}$ when the animals were fed on diets supplemented with seven levels of casein, gluten and urea, is demonstrated in Fig. 3. The urinary $N$ remained constant when the animals were given the various levels of gluten $N$. On the other hand, when the diets were supplemented with casein or urea, an increase in $\mathrm{N}$ intake was followed by an increase in the urinary $\mathrm{N}$ excretion.

In general, the amounts of urinary $N$ excreted when the two rams received casein were higher than those when the animals received urea as the sole source of $\mathrm{N}$. The levels of urinary $N$ when the animals were given a $N$-free diet were 0.74 and $I \cdot I 7 \mathrm{~g} /$ day respectively for rams nos. 655 and 749 (before they received gluten).

In the three successive experimental periods the $\mathrm{N}$ reserves of the animals were different at the onset of each period. The urinary $\mathrm{N}$ was slightly higher at the beginning of the period in which casein was given than at the beginning of the period with urea 
or gluten. It is assumed that the value $K$ is not affected by the different states of $\mathrm{N}$ istores except in severe cases of depletion (Allison, 1949). However, it is very difficult to effect complete depletion of $\mathrm{N}$ stores in ruminants. The verification of this assumption as applied to sheep is presently under investigation.

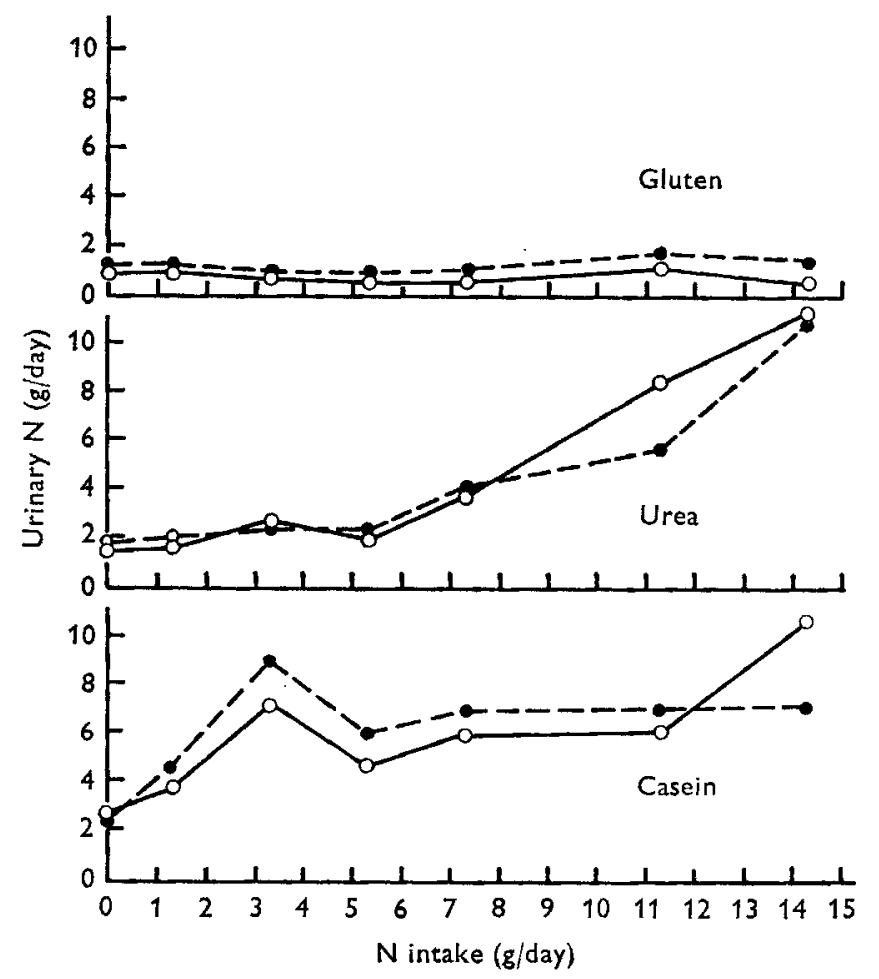

Fig. 3. Relationship between nitrogen intake and urinary $\mathrm{N}$ in rams nos. 655, $\mathrm{O}-\mathrm{O}$, and 749, -.- receiving diets containing casein, gluten or urea.

Relationship between $N$ intake and absorbed $N$. The relationship between $\mathrm{N}$ intake and absorbed $\mathrm{N}$ in animals given the seven levels of casein, gluten or urea, is demonstrated in Fig. 4. A linear relationship between $\mathrm{N}$ intake and absorbed $\mathrm{N}$ was found when the animals received these nitrogenous compounds at the first five levels.

Relationship between $N$ intake and $N$ retention. When $N$ intake was plotted against $N$ retention for diets supplemented with casein, gluten and urea a straight line relationship (Fig. 5) was obtained up to a $\mathrm{N}$ intake of $5.33 \mathrm{~g} \mathrm{~N}$ for urea, I I.33 g N for casein and $7.33 \mathrm{~g} \mathrm{~N}$ for gluten. With casein the point at the level of $3.33 \mathrm{~g} \mathrm{~N}$ intake was clearly out of line with the other levels. This was probably due to experimental error mostly relating to the condition of the animals due to the long period of $\mathrm{N}$ fasting (27 days). Values for $\mathrm{N}$ retention in these curves were plotted after subtracting the metabolic faecal $\mathrm{N}$ and the endogenous urinary $\mathrm{N}$ from faecal $\mathrm{N}$ and urinary $\mathrm{N}$ respectively. The slopes of the regressions ( $\mathrm{N}$ retention index of $\mathrm{N}$ intake) were 0.69 , $\mathrm{I} .02$ and 0.97 respectively for animals given the diets containing casein, gluten and urea. 
Relationship between absorbed $N$ and $N$ retention. Fig. 6 shows the relationship between absorbed $\mathrm{N}$ and $\mathrm{N}$ retention when the rams received the various levels of casein, gluten or urea. A linear relationship was observed with gluten, urea and casein

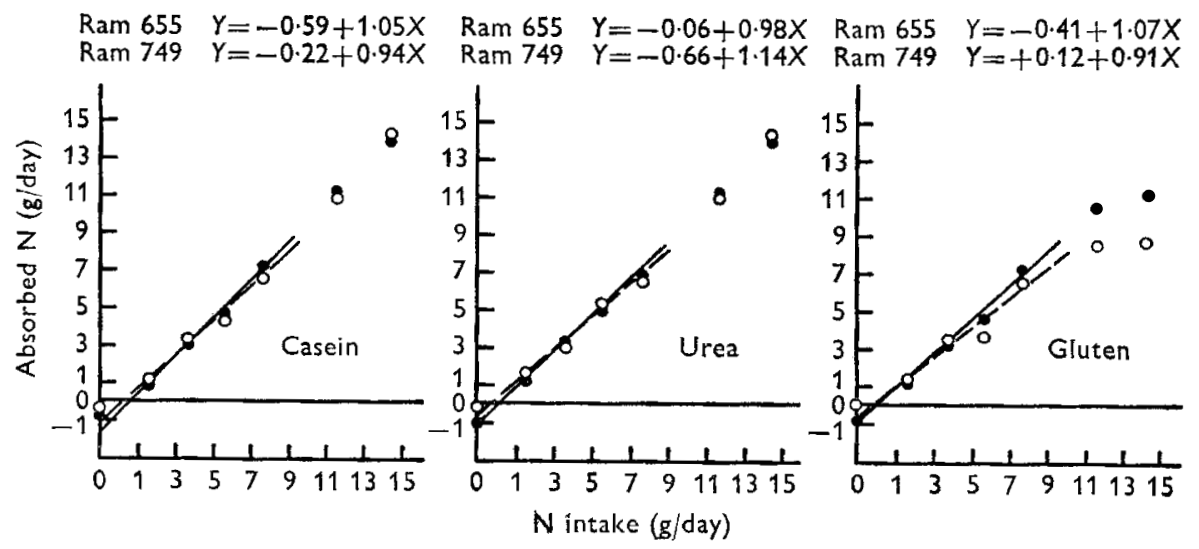

Fig. 4. Relationship between nitrogen intake and absorbed $\mathrm{N}$ in rams nos. 655 , - , and 749 , ---0 , receiving diets containing casein, urea or gluten, with regression equations for the relationship in each ram.

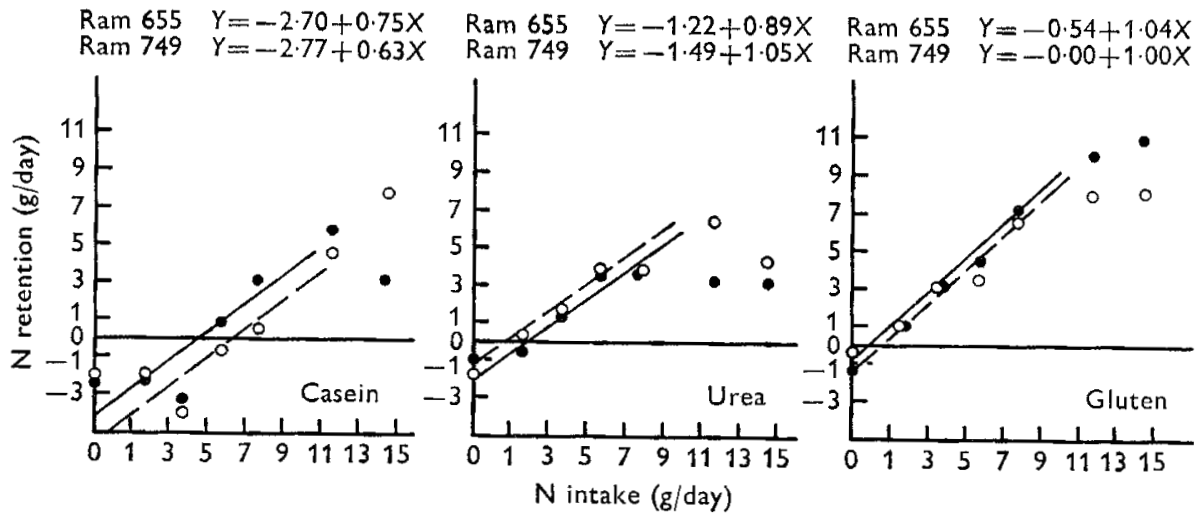

Fig. 5. Relationship between nitrogen intake and $\mathrm{N}$ retention in rams nos. $655,-1$, and $749,0--0$, receiving diets containing casein, urea or gluten, with regression equations for the relationship in each ram.

up to the levels of $\mathrm{x} \cdot 33,5.33$ and $7.33 \mathrm{~g} \mathrm{~N}$ respectively. The average slopes of regressions ( $N$ retention index for the absorbed $N$ or the 'biological value') were 0.65 , 1.05 and 0.83 respectively for casein, gluten and urea. As shown in Table $I$, the maximum 'biological value' for casein was observed with ram no. 655 when the intake was I I.33 g N/day, and with ram no. 749 when the intake was $14 \cdot 33 \mathrm{~g} \mathrm{~N} /$ day. For urea the maximum 'biological value' was found at an intake of $5.33 \mathrm{~g} \mathrm{~N} /$ day with both rams. With gluten, the 'biological value' was almost constant for all levels of intake.

Measurement of urinary $N$ in sheep given cottonseed meal gluten and a $N$-free diet. 
Fig. 7 shows the urinary $\mathrm{N}$ as determined for the three successive periods of feeding with cottonseed meal, rice gluten and the $\mathrm{N}$-free diet. It is shown that the level of urinary $N$ dropped from a level of $4-7 \mathrm{~g}$ with cottonseed meal to a constant level of approximately $\mathrm{I} g /$ day $13-16$ days after the feeding with gluten began. This was the same level of urinary $\mathrm{N}$ as on a $\mathrm{N}$-free diet.
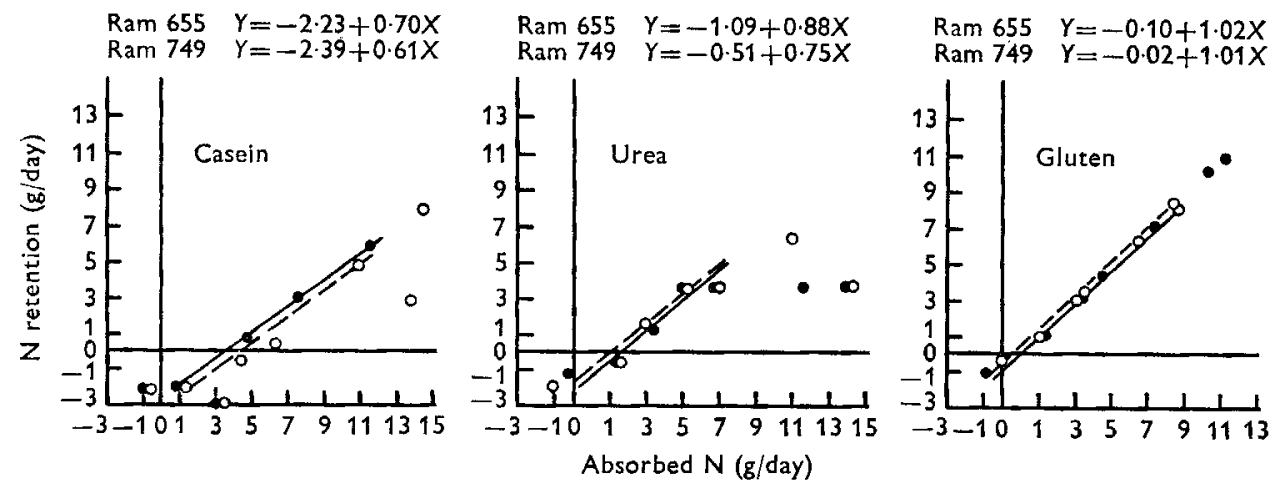

Fig. 6. Relationship between absorbed nitrogen and $\mathrm{N}$ retention in rams nos. $\mathbf{6}_{55}$, 749, 0 , receiving diets containing casein, urea or gluten, with regression equa the relationship in each ram.

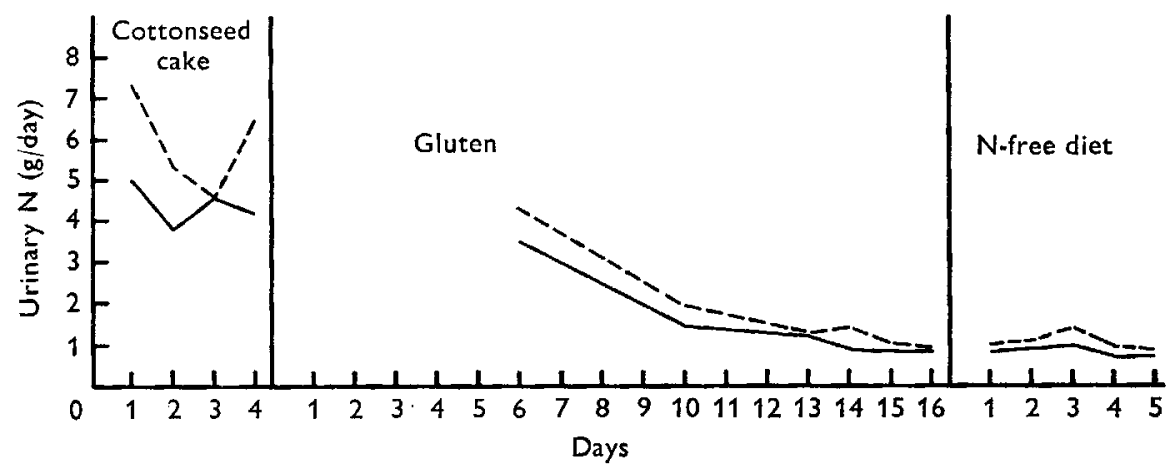

Fig. 7. Urinary nitrogen level in rams nos. $655,-$, and $749,---$, fed on diets containing cottonseed cake, or gluten, or the N-free diet.

Table 1. The 'biological value'* of gluten, urea and casein at various levels of nitrogen intake, determined with the two rams nos. 655 and 749

\begin{tabular}{|c|}
\hline $\begin{array}{l}\text { Level of } \\
\mathrm{N} \text { intake } \\
\text { (g/day) }\end{array}$ \\
\hline 0.00 \\
\hline I' 33 \\
\hline $3 \cdot 33$ \\
\hline $5 \cdot 33$ \\
\hline $7 \cdot 33$ \\
\hline I I 33 \\
\hline 1433 \\
\hline
\end{tabular}

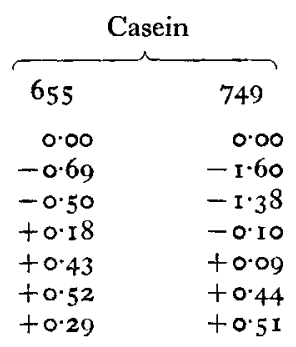

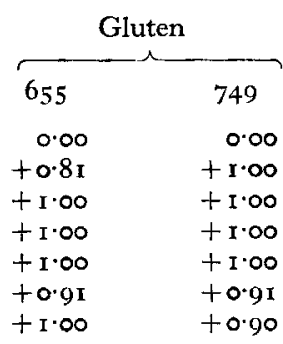

\begin{tabular}{cc}
\multicolumn{2}{c}{ Urea } \\
\hline 655 & 749 \\
0.00 & 0.00 \\
+0.27 & +0.26 \\
+0.44 & +0.59 \\
+0.76 & +0.77 \\
+0.51 & +0.58 \\
+0.30 & +0.59 \\
+0.21 & +0.31
\end{tabular}

* Determined by the method of Allison (r949). 


\section{DISCUSSION}

When two rams received seven levels of $\mathrm{N}$ in the form of gluten, casein or urea, it was found that the amount of $\mathrm{N}$ excreted in the faeces increased as the gluten intake increased, whereas this trend was not observed with casein and urea. 'Thus, with casein and urea, the faecal $\mathrm{N}$ of the animals when on a $\mathrm{N}$-free diet (metabolic faecal $\mathrm{N}$ ) was similar to that when they had various levels of $\mathrm{N}$ intake. This indicated that under our experimental conditions both urea and casein were almost completely absorbed ( 98 , 97 and $92,95 \%$ for animals 655 and 749 respectively) and that the metabolic faecal $\mathrm{N}$ was independent of the level of $\mathrm{N}$ intake. Under these conditions, taking the metabolic faecal $\mathrm{N}$ as the average of the faecal $\mathrm{N}$ outputs of the two animals when kept on all levels of $\mathrm{N}$ intake, a value of $0.35^{8} \mathrm{~g} \mathrm{~N} / \mathrm{I} 00 \mathrm{~g}$ dry matter consumed, was obtained. This figure is similar to that of $0.366 \mathrm{~g} \mathrm{~N} / \mathrm{I} 00 \mathrm{~g}$ dry matter obtained by Elliot \& Topps (1963), and is lower than the value of $0.5 \mathrm{~g}$ often accepted for ruminants (Maynard $\&$ Loosli, 1956).

When the animals were fed on gluten, the urinary $\mathrm{N}$ was constant and equivalent to the value obtained with the $\mathrm{N}$-free ration (Fig. 3 ). This is indirect evidence that $K$ for this protein for ruminants is equivalent to unity (Allison, 1949). On the other hand, an increase in $\mathrm{N}$ intake was followed by a rise in the urinary $\mathrm{N}$ excretion when the animals were kept on casein and urea. It is noteworthy that the urinary $N$ was highest when casein was the supplement. The increased urinary $\mathrm{N}$ on the casein diet and the small excretion of urinary $N$ on the gluten diet, is probably a reflection of the levels of ammonia in the rumen of these animals. Like the ruminal ammonia, the urinary $\mathrm{N}$ of the rams when they received urea was lower than it was when they received casein. These findings agree with the results of Lewis (1957), Abou Akkada \& el-Shazly (1965), Tagari, Drori, Ascarelli \& Bondi (1964) and Abou Akkada \& Osman (1967), which showed that there was a positive correlation between the amount of urinary $\mathrm{N}$ excreted, the level of urea in the blood and the level of ammonia in the rumen contents.

Melnick \& Cowgill ( 1937 ) proposed that minimum amounts of dietary protein $\mathrm{N}$ necessary to maintain $\mathrm{N}$ equilibrium should be quantitatively determined. This amount was obtained in the $\operatorname{dog}$ by plotting $\mathrm{N}$ intake against $\mathrm{N}$ balance in the region of $\mathrm{N}$ equilibrium. When this procedure was applied to the present results, it was found that approximately $5.33 \mathrm{~g}$ casein $\mathrm{N}$ and $\mathrm{I} \cdot 33 \mathrm{~g}$ urea or gluten $\mathrm{N}$ were sufficient to maintain each ram in $\mathrm{N}$ equilibrium. This procedure of using the minimum amount of protein required to produce a zero $\mathrm{N}$ balance is seriously criticized because the animals used for the tests may be in different physiological states and especially may have varying $\mathrm{N}$ reserves at the beginning of the experiment; this would clearly influence the time taken for equilibrium to be reached with any particular intake of $\mathrm{N}$. The fact that lower levels of urea $\mathrm{N}$ than of casein $\mathrm{N}$ were required to maintain $\mathrm{N}$ balance may, therefore, have been a reflection of the initial degree of depletion of the $\mathrm{N}$ reserves. The slopes $(K)$ of the regression equation relating $\mathrm{N}$ intake and $\mathrm{N}$ retention have been termed the $\mathrm{N}$ balance indexes of dietary $\mathrm{N}$ intake (Allison, Anderson \& Seely, I946), since they demonstrate the rate at which dietary $\mathrm{N}$ fills the protein stores of the body. Consequently, these indexes are a function of the nutritive value of the dietary $N$. 
In the present experiment the average $\mathrm{N}$ balance indexes of $\mathrm{N}$ intake were $\mathrm{I} \cdot 02$, 0.97 and 0.69 respectively for gluten, urea and casein. It is, therefore, suggested that the nutritive value of urea when fed to adult sheep in quantities which do not exceed $5 \mathrm{~g} \mathrm{~N}$ and in the presence of readily available carbohydrates, such as starch, is approximately similar to that of gluten and higher than that of casein.

The present observations also suggest a linear relationship between the absorbed $\mathrm{N}$ and the $\mathrm{N}$ retention when the sheep were given seven different levels of casein, gluten and urea $\mathrm{N}$. The slopes $(K)$ of these lines are termed the $\mathrm{N}$ balance indexes of absorbed N (Allison et al. 1946) because they measure the rate at which the protein stores of the body are being filled. $K$, the slopes of the curves, represent mathematically the retained $\mathrm{N}$ as a fraction of the absorbed $\mathrm{N}$ which is, according to Mitchell, the 'biological value' of the protein. Allison (1949) considered it a function of the biological value rather than the biological value itself and suggested a new term for measuring $\mathrm{N}$ utilization, i.e. the net protein value. The $\mathrm{N}$ balance indexes of absorbed $\mathrm{N}$ in the present investigations as calculated from the linear portions of the curves in Fig. 5, were found to be $\mathrm{I} \cdot 05,0.83$ and 0.65 for gluten, urea and casein respectively, which suggests that the 'biological value' of urea when given in small doses to sheep can be higher than that of casein and lower than that of gluten. The $\mathrm{N}$ balance index of absorbed $\mathrm{N}$ of gluten and casein have been found to be 0.40 and 0.80 respectively in monogastric animals (Allison, I949). The lower index of gluten in non-ruminants is due to the absence of some amino acids such as lysine. When gluten is fed to ruminants, it is mixed in the rumen with the microbial proteins containing the essential amino acids (Loosli, Williams, Thomas, Ferris \& Maynard, 1949), with the result that the biological value of the gluten is considerably improved.

The present finding that rice gluten has a 'biological value' of $\mathrm{x} \cdot \mathrm{O}$ is of great significance in ruminant nutrition. Allison, Seely, Brown \& Ferguson (I947) determined the 'biological value' of some proteins in dogs by using the equation $U=(\mathrm{I}-K)$ $A+U_{0}$. To determine the endogenous urinary $\mathrm{N}$ the animal must be put on a $\mathrm{N}$-free diet, but ruminants will not readily consume such a diet and it may have harmful effects on their health. However, theoretically, $U_{0}$ (endogenous urinary $N$ ) can be determined by feeding the animals a protein such as rice gluten with a $\mathrm{N}$ balance index of absorbed $\mathrm{N}$ (biological value) of $\mathrm{I} \cdot \mathrm{O}$. Under these conditions if gluten is given in amounts sufficient to bring the animals to zero $\mathrm{N}$ balance, the urinary $\mathrm{N}$ excreted $(U)$ will be equal to $\left(U_{0}\right)$. This conclusion is in agreement with the results obtained here which indicated that, when the animals were given various levels of gluten $\mathrm{N}$, the urinary $\mathrm{N}$ was constant and equivalent to the urinary $\mathrm{N}$ at zero $\mathrm{N}$ intake. $\mathrm{It}$ is, therefore, concluded that the use of a protein such as rice gluten will facilitate the determination of the biological value of any nitrogenous compound when fed to ruminants.

The estimation of $U_{0}$ as described above, made it relatively easy to determine the 'biological value' $(K)$ of gluten, casein and urea at various levels of $\mathrm{N}$ intake by using the equation: $K=\left[A-\left(U-U_{0}\right)\right] / A$, where $A$ represents the absorbed $\mathrm{N}$ and $U$ the urinary $\mathrm{N}$ (Allison, 1949). When this equation was used, the values given in 'Table I were obtained. It was shown that the highest 'biological values' for urea and casein were observed when the levels of intake were 5.33 and II.33 $\mathrm{g} \mathrm{N} /$ day respectively. 
With gluten the value $I \cdot O$ was obtained with most of the levels of intake. It is of interest to note that the present observations have thrown some light on the critical level beyond which the feeding of urea would decrease in value, and it is suggested that the critical level should be taken into consideration when urea is used to replace dietary protein.

\section{REFERENCES}

Abou Akkada, A. R. \& el-Shazly, K. (1965). F. agric. Sci., Camb. 64, 251.

Abou Akkada, A. R. \& Osman, H. El Sayed (I967). F. agric. Sci., Camb. 69, 25.

Ahmed, I. A. \& el-Shazly, K. (1960). Alex. F. agric. Res, 8, 217.

Allison, J. B. (r 949). Adv. Protein Chem. 5, I55.

Allison, J. B., Anderson, J. A. \& Seely, R. D. (1946). Ann. N.Y. Acad. Sci. 47, 245.

Allison, J. B., Seely, R. D., Brown, J. H. \& Ferguson, F. P. (1947). Fedn Proc. Fedn Am. Socs exp. Biol. 6, 234 .

Association of Official Agricultural Chemists (I955). Official Methods of Analysis. Washington, D.C.: Association of Official Agricultural Chemists.

Chalmers, M. I. \& Synge, R. L. M. (1954). Adv. Protein Chem. 9, 93.

Chibnall, A. C., Rees, M. W. \& Williams, E. F. (1943). Biochem. F. 37, 354.

Elliott, R. C. \& Topps, J. H. (1963). Br. F. Nutr. 17, 539.

Hawk, P. B., Oser, B. L. \& Summerson, W. H. (1952). Practical Physiological Chemistry, 12th ed., p. 564. London: J. A. Churchill.

Lewis, D. (1957). F. agric. Sci., Camb. 48, 438.

Loosli, J. K., Williams, H. H., Thomas, W. E., Ferris, F. H. \& Maynard, L. A. (I949). Science, N. Y., Iro, 144 .

Markham, R. A. (I942). Biochem. $\mathcal{F} .36,790$.

Maynard, L. A. \& Loosli, J. K. (1956). Animal Nutrition, 4th ed. New York, Toronto, London: McGraw-Hill Book Company Inc.

Melnick, D. \& Cowgill, G. R. (1937). F. Nutr. r3, 40r.

Mitchell, H. H. (1943). F. Anim. Sci. 2, 263.

Tagari, H., Drori, Y., Ascarelli, I. \& Bondi, A. (r964). Br. f. Nutr. 18, 333. 